\title{
Intussusception Presenting with Malignant Hypertension and Lethargy
}

\author{
Andra de Vries ${ }^{a} \quad$ Nilou Ashtiani ${ }^{b} \quad$ Nazanin Ahmadi ${ }^{c}$ Roel Bakx \\ Annelies Walrave-bij de Vaate ${ }^{f} \quad$ Arend Bökenkamp $^{d}$ \\ ${ }^{a}$ Department of Pediatric Intensive Care, University Medical Center Groningen, Groningen, \\ Departments of ${ }^{b}$ Pediatrics, ${ }^{c}$ Radiology and ${ }^{d}$ Pediatric Nephrology, VU University Medical \\ Center, and ${ }^{\mathrm{e}}$ Department of Pediatric Surgery, Pediatric Surgical Center, Amsterdam, and \\ fDepartment of Pediatrics, MC Zuiderzee, Lelystad, The Netherlands
}

\section{Key Words}

Malignant hypertension · Lethargy · Intussusception

\begin{abstract}
The most common cause of malignant hypertension in children is renal or renovascular pathology. The combination with lethargy suggests a diagnosis of hypertensive crisis with hypertensive encephalopathy. Here, we present a case of severe hypertension with lethargy as the sole presenting symptoms of ileocecal intussusception. Both normalized following surgical repositioning. We conclude that malignant hypertension and lethargy can be presenting symptoms of intussusception.

(c) 2013 S. Karger AG, Basel
\end{abstract}

\section{Introduction}

Symptomatic hypertension in children is usually secondary and most often due to renal parenchymal disease or renovascular pathology. Other causes include coarctation of the aorta, elevated intracranial pressure or an endocrine origin [1]. Lethargy in young children has a broad differential diagnosis and may result from both neurological and nonneurological diseases. The combination of lethargy and severe hypertension suggests a hypertensive emergency with neurological end-organ damage [2]. Here, we describe a 10-month-old boy presenting with lethargy and severe arterial hypertension caused by ileocecal intussusception. 


\section{Case Presentation}

A 10-month-old boy with a body weight of $9.6 \mathrm{~kg}$ presented with progressive lethargy. His past medical history was unremarkable. He had suffered from gastritis 2 weeks before and started vomiting again 2 days before admission. The patient had no fever, excessive sweating or diarrhea, and his urine output was normal. Physical examination revealed a sleepy but easily arousable infant with a heart rate of 160 per minute, a respiration rate of 32 per minute and a body temperature of $37.7^{\circ} \mathrm{C}$. On all four extremities, a blood pressure of $135 / 95 \mathrm{~mm} \mathrm{Hg}$ was measured, a value above the 99 th percentile (P) by age and height (e.g. P 95th is $103 / 56 \mathrm{~mm} \mathrm{Hg}$ ). There were no signs of meningitis or intracranial hypertension, no abnormalities in sensibility and strength, and reflexes were normal. Cardiopulmonary examination revealed no heart murmurs, and breath sounds were normal. The abdomen was not painful to palpation and there were no masses. No edema was found, and the skin was unremarkable. Based on the combination of hypertensive crisis and the neurological findings, the diagnosis of malignant hypertension was made and the patient was admitted to our pediatric intensive care unit for evaluation and intravenous antihypertensive therapy [1-3]. Nicardipine at $1 \mathrm{mcg} / \mathrm{kg} / \mathrm{min}$ lowered his blood pressure to an acceptable level of 105/55 mm Hg (P 95th) within a few hours.

Laboratory results showed a normal complete blood cell count, serum electrolytes ( $\mathrm{Na}$ $137 \mathrm{mmol} / \mathrm{l}, \mathrm{K} 4.1 \mathrm{mmol} / \mathrm{l}, \mathrm{Cl} 104 \mathrm{mmol} / \mathrm{l}$ ), creatinine $13 \mu \mathrm{mol} / \mathrm{l}$, urea $3.6 \mathrm{mmol} / \mathrm{l}$ and glucose $5.6 \mathrm{mmol} / \mathrm{l}$. Glomerular filtration rate was $118 \mathrm{ml} / \mathrm{min}$, and blood lactate as well as ammonia levels were normal. An arterial blood gas analysis revealed a mild metabolic acidosis with respiratory compensation ( $\mathrm{pH} 7.40$, bicarbonate $17.7 \mathrm{mmol} / \mathrm{l}, \mathrm{pCO}_{2} 29$ $\mathrm{mm} \mathrm{Hg}$ ).

A computed tomography of the brain revealed no intracranial bleeding, no tumor and no signs of elevated intracranial pressure. An abdominal ultrasound showed normal kidneys without hydronephrosis, and Doppler studies were unremarkable. On the ultrasound, an abdominal mass with the characteristic 'target sign' of an ileocecal intussusception was visualized in the right lower quadrant (fig. 1). Radiographically guided hydrostatic reduction with water-soluble contrast failed. Laparotomy was performed, which confirmed the diagnosis of intussusception. After repositioning, intestinal perfusion was adequate and bowel resection was not necessary. The anesthetics used during the surgery had no major influence on the blood pressure. Following surgery, the mental status returned to normal and antihypertensive medication could be discontinued. His blood pressure decreased to a normal level (P 50th 90/40 mm Hg).

\section{Discussion}

In the case presented, intussusception was diagnosed during the workup for suspected renal or renovascular pathology, which is the major cause of secondary hypertension in children [1]. Although uncommon, severe hypertension has been noted in several case reports on children with intussusception (table 1) [3-6].

Intussusception is a common cause of bowel obstruction in children between 3 months and 5 years of age. A proximal segment of the intestine telescopes into a distal segment of the intestine, causing obstruction of the bowel passage, constriction of the mesentery and venous blood flow obstruction. Prolonged ischemia eventually leads to intestinal perforation if left untreated. The pathogenesis of intussusception is thought to be secondary to an imbalance of longitudinal forces along the intestinal wall, with a mass (for example enlarged 
lymph nodes) acting as a lead in combination with a dysfunctional pattern of peristalsis. An important predisposing factor for the development of intussusception is viral or bacterial gastroenteritis [7]. It has been suggested that overproduction of nitric oxide from local inflammatory reactions might lead to the relaxation of intestinal smooth muscles and the ileocecal valve [8].

The classical symptoms of intussusception at presentation are acute abdominal pain, vomiting, rectal blood loss and a palpable abdominal mass [7]. Lethargy has been reported in $16-38 \%$ of all cases and may be the presenting and main clinical feature of intussusception [9]. Kleizen et al. [9] noted that patients with neurological abnormalities were significantly younger and presented with a shorter duration of symptoms.

Intussusception has significant morbidity and mortality if not treated immediately. Reposition is done preferably by nonsurgical techniques using air or liquid contrast media. A symptom duration of more than $5 \mathrm{~h}$ before intervention is associated with a lower success rate and an increased rate of surgical intervention and bowel resection [7].

In our patient, the clinical picture was dominated by severe arterial hypertension in combination with lethargy, which suggested a hypertensive emergency with hypertensive encephalopathy or even reversible posterior leukoencephalopathy [2]. Yet, the differential diagnosis of lethargy in young infants is broad and includes both primary neurological and nonneurological diseases such as intussusception [10]. The pathophysiology of lethargy in intussusception has been attributed to the release of neuromediators (endotoxins, neurohormones, and endorphines) from the ischemic intestine [11]. Sympathetic nerve stimulation by pain and release of neuromediators from the intestine may also underlie blood pressure elevation in this condition. Still, it is remarkable that altered consciousness and blood pressure elevation are only variably present and rarely observed with other causes of ischemic intestinal pathology.

In general, the neurological symptoms disappear following surgery or successful hydrostatic reposition. This is also the case with hypertension, although it took 5 months until the blood pressure had returned to normal in 1 of the cases reported [6].

In conclusion, intussusception should be considered in the differential diagnosis in young children presenting with lethargy and hypertension even in absence of classical signs. Abdominal examination should be given special attention as prolonged duration of symptoms leads to poorer outcomes. We believe that abdominal ultrasound should be part of the initial workup in any young child with hypertension and/or lethargy (as blood pressure assessment may not be the first diagnostic step taken in a lethargic child).

\section{Disclosure Statement}

The authors have no conflicts of interest to declare.

\section{References}

1 National High Blood Pressure Education Program Working Group on High Blood Pressure in Children and Adolescents: The fourth report on the diagnosis, evaluation, and treatment of high blood pressure in children and adolescents. Pediatrics 2004;114:555-576.

-2 Pavlakis SG, Frank Y, Chusid R: Hypertensive encephalopathy, reversible occipitoparietal encephalopathy, or reversible posterior leukoencephalopathy: three names for an old syndrome. J Child Neurol 1999;14:277-281.

3 Barton LL, Chundu K: Intussusception associated with transient hypertension. Pediatr Emerg Care 1988;4:249-250. 
4 Prichard JG, Pakula AG: Hypertension and intussusception. Clin Pediatr (Phila) 1987;26:196-198.

5 Paget C, Rossignol AM, Durand C, Bourdat-Michel G: Hypertensive manifestation of an acute intestinal intussusception (in French). Arch Pédiatr 1999;6:640-642.

-6 Hida M, Ettair S, Mouane N, Erreimi N, Afifi M, Bouchta F: Acute intestinal intussusception and arterial hypertension (in French). Arch Pédiatr 2000;7:216.

-7 Jenke AC, Klaassen-Mielke R, Zilbauer M, Heininger U, Trampisch H, Wirth S: Intussusception: incidence and treatment - insights from the nationwide German surveillance. J Pediatr Gastroenterol Nutr 2011;52: 446-451.

8 Cserni T, Paran S, Puri P: New hypothesis on the pathogenesis of ileocecal intussusception. J Pediatr Surg 2007;42:1515-1519.

-9 Kleizen KJ, Hunck A, Wijnen MH, Draaisma JMTh: Neurological symptoms in children with intussusception. Acta Paediatr 2009;98:1822-1824.

10 Sassower KC, Allister LM, Westra SJ: Case records of the Massachusetts General Hospital. Case 12-2012: a 10-month-old girl with vomiting and episodes of unresponsiveness. N Engl J Med 2012;366:1527-1536.

11 Conway EE: Central nervous system findings and intussusception: how are they related? Pediatr Emerg Care 1993;9:15-18.

Table 1. Characteristics of described patients with hypertension and intussusception

\begin{tabular}{|c|c|c|c|c|c|c|c|c|}
\hline Report & Sex & $\begin{array}{l}\text { Age, } \\
\text { months }\end{array}$ & $\begin{array}{l}\text { Presenting } \\
\text { symptoms }\end{array}$ & $\begin{array}{l}\mathrm{BP}(\mathrm{mm} \mathrm{Hg}) \text { at } \\
\text { admission } \\
\text { (non invasive) }\end{array}$ & $\begin{array}{l}\text { Duration } \\
\text { till } \\
\text { diagnosis }\end{array}$ & & ervention & $\begin{array}{l}\text { Discharge BP, } \\
\mathrm{mm} \mathrm{Hg}\end{array}$ \\
\hline $\begin{array}{l}\text { Barton } \\
{[3]}\end{array}$ & M & 3 & $\begin{array}{l}\text { Vomiting } \\
\text { Lethargy } \\
\text { Hyperten- } \\
\text { sion }\end{array}$ & $\begin{array}{l}\text { 140/.. } \\
\text { (Doppler) }\end{array}$ & $>48 \mathrm{~h}$ & $\begin{array}{l}1 \\
2\end{array}$ & $\begin{array}{l}\text { Barium enema failed } \\
\text { Ileocolic reanastomosis } \\
\text { after } \\
\text { resection }\end{array}$ & 75-95/.. \\
\hline $\begin{array}{l}\text { Prich- } \\
\text { ard } \\
{[4]}\end{array}$ & M & 6 & $\begin{array}{l}\text { Vomiting } \\
\text { Lethargy } \\
\text { Hyperten- } \\
\text { sion }\end{array}$ & $180 / 116$ & $>48 \mathrm{~h}$ & $\begin{array}{l}1 \\
2\end{array}$ & $\begin{array}{l}\text { Barium enema failed } \\
\text { Laparotomy } \\
\text { (resection Meckels } \\
\text { diverticulum) }\end{array}$ & 80/.. \\
\hline $\begin{array}{l}\text { Prich- } \\
\text { ard } \\
{[4]}\end{array}$ & M & 9 & $\begin{array}{l}\text { Apathy } \\
\text { Irritability } \\
\text { Anorexia } \\
\text { Hyperten- } \\
\text { sion }\end{array}$ & $140 / 95$ & $>48 \mathrm{~h}$ & 2 & $\begin{array}{l}\text { Barium enema failed } \\
\text { Laparotomy } \\
\text { (lymphadenitis, ileopexy) }\end{array}$ & Normal \\
\hline $\begin{array}{l}\text { Paget } \\
{[5]}\end{array}$ & M & 8 & $\begin{array}{l}\text { Vomiting } \\
\text { Apathy } \\
\text { Hyperten- } \\
\text { sion }\end{array}$ & $130 / 80$ & $<24 \mathrm{~h}$ & 1 & Barium enema & Normal \\
\hline $\begin{array}{l}\text { Hida } \\
\text { [6] }\end{array}$ & $\mathrm{F}$ & 8 & $\begin{array}{l}\text { Vomiting } \\
\text { Diarrhea } \\
\text { Apathy } \\
\text { Hyperten- } \\
\text { sion }\end{array}$ & $132 / 68$ & $>48 \mathrm{~h}$ & 1 & Laparotomy & $\begin{array}{l}? \\
\text { Normal after } \\
5 \text { months }\end{array}$ \\
\hline $\begin{array}{l}\text { de } \\
\text { Vries } \\
\text { [this } \\
\text { report] }\end{array}$ & M & 10 & $\begin{array}{l}\text { Lethargy } \\
\text { Vomiting } \\
\text { Hyperten- } \\
\text { sion }\end{array}$ & $135 / 95$ & $<48 \mathrm{~h}$ & 2 & $\begin{array}{l}\text { Barium enema failed } \\
\text { Laparotomy (repositioning) }\end{array}$ & $90 / 40$ \\
\hline
\end{tabular}


Case Reports in

Nephrology and

Urology

\begin{tabular}{l|l}
\hline Case Rep Nephrol Urol 2013;3:105-109 \\
\hline DOI: $10.1159 / 000353849$ & $\begin{array}{l}@ 2013 \text { S. Karger AG, Basel } \\
\text { www.karger.com/cru }\end{array}$ \\
\hline
\end{tabular}

de Vries et al.: Intussusception Presenting with Malignant Hypertension and Lethargy
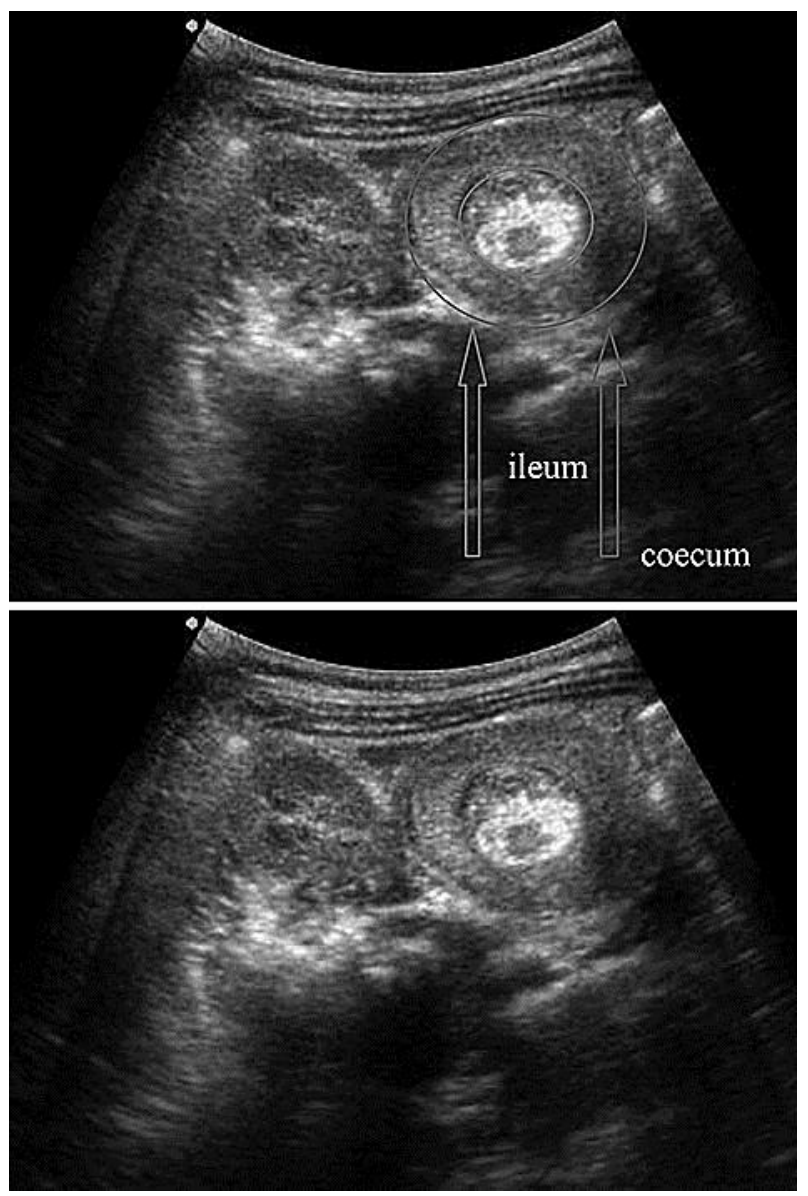

Fig. 1. Abdominal ultrasound. Target sign of an ileocecal intussusception in the right lower quadrant (arrows). The classic ultrasound image of intussusception is a 'bull's eye', 'coiled spring' or 'target sign' lesion (intraluminal mass or intussusceptum) representing layers of the intestine within the intestine. 